\title{
研究ノ一ト
}

\section{ニッケルメッキ液中の懸濁物がメッキ皮膜に及ぼす 影響について}

Effect of Suspension in Electroplating Solution on Bright Nickel Plating

\section{1. 緒言}

メッキ液中の微細な眯濁物がメッキ製品の外観および 耐食性に大きな影響を及ぼすことは衆知の事であり，ピ ンホールやザラッキなどの発生原因およびその機構はそ れぞれ究明されている。しかし，メッキ液中の微細な懸 濁物の量とザラッキなどの関係を数量的にあつかったも のがなく, 単に口過によって, これの解汏を行なってい る現状である。

本研究では光沢ニッケルメッキ液の清澄度 (濁度) の 基準をもうけ, 液中の微細な懸濁物が,メッキの仕上ガ リにどのような影響を及ぼすかを調べた。

\section{2. 実 験 方 法}

\section{2-1 舁濁物の標準組成および濁度の基準決定}

メッキ液に混入する懸濁物は，各工場によって同一の ものでないから，これを基準化することははなはだ困難 であり危険でああるが，いずれにしてる現場に即応した ものを考觉ねばならない。

このため, 光沢ニッケルメッキ液中の懸淘物を一定期 間口過機で捕集し分析したところ，その大部分は

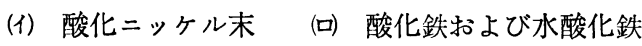

(ソ) 黄色系ケイソウ土末怙よび炭素末

であることが判明した。このため懸濁物の標準組成を

酸化ニッケル末 $30 \%$ 酸化第二鉄末 $50 \%$

水酸化第二鉄 $20 \%$

の混合物とし, 水の濁度が白陶土 $1 \mathrm{ppm}$ 懸濁している むのを, 濁度 1 度としたごとく, これら混合組成物が光 沢ニッケルメッキ液に $1 \mathrm{ppm}$ 懸濁した液を濁度 1 度と して以後の実験をすすめた。

\section{$2-2$}

光沢ニッケルメッキ夜のごとく着色している夜の中の 微量な懸濁物の量を知ることは非常に困難である。特に

* 株式会社三進製作所（名古屋市中村区龟島町）

Sanshin Filter Manufacturing Co., Ltd.
柳一下相三 郎* - 桐 沢 忠*

Aisaburo YAGISHITA* and Atsushi KIRISAWA*

メッキ液は硫酸ニッケルなどの濃度によって着色の度合 が異なるため, 試験液の濃度による呈色を考慮し，

$$
\begin{array}{lrl}
\text { 硫酸 } & =ッ ケ ル & 200 \sim 300 \mathrm{~g} / l \\
\text { 塩化 } & =ッ \text { ケ } & 45 \mathrm{~g} / l
\end{array}
$$

の範用で，懸濁物を混入させ濁度線図を作成した。東洋 口紙 No. $5 \mathrm{C}$ の口過液をその濃度に淤ける濁度 0 度の 基準とした。第 1 図は濁度線図を示す。

線図の使用方法

試験液は, 主として硫酸ニッケルの濃度により呈色 の度合が異なるので, 東洋口紙 No. $5 \mathrm{C}$ て懸濁物を除 去した後, $38 \phi$ 試験管に取り,フィルター $500 \mathrm{~m} \mu$ に より光電比色計で透過率を測定し, 横軸の透過率に読 みを合わせた垂直線を引く。次に, 試験液を口過せ ず,そのまま同様に $38 \phi$ 試験管で透過率を測定し， 左縦軸の該当目盛から横軸に平行な直線を引き，さき の横軸からの垂直線との交点を求めて, その点の濁度 を右緃軸の目盛について読むと, これが試験液の濁度 となる。

\section{2-3 被メッキ物の型状および材質}

$0.2 \mathrm{dm}^{2}$ の鉄素地板を片面バフ研摩仕上ゲしたもので 型状は第 2 図に示す。

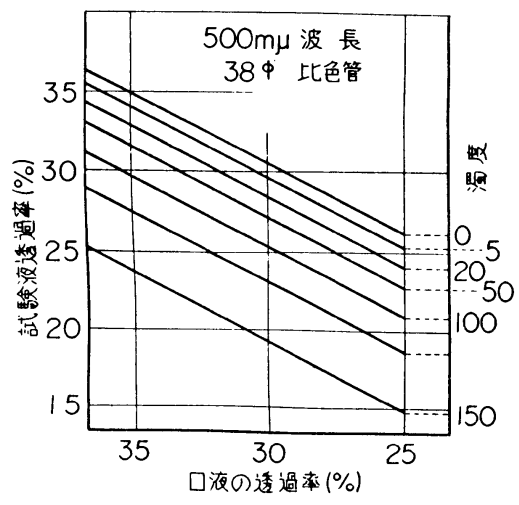

第1図濁度線図 


\section{2-4 メッキ液の組成および条件}

研摩扣よび脱脂方法は，一般に用いられている方法を

採用し，紙面の都合上割愛する。

(i) 銅メッキ液

(1) 組 成

$\begin{array}{lc}\text { シアン化第一銅 } & 60 \mathrm{~g} / l \\ \text { シアン化ナトリウム } & 80 " \\ \text { カセイカリウム } & 20 " \\ \text { チオシアン化カリウム } & 15 " \\ \mathrm{pH} & 12.0 \sim 12.4\end{array}$

(口) 操作条件

温度 $\quad 60 \sim 70^{\circ} \mathrm{C}$ 液量 $4 l$

メッキ時間 $25 \mathrm{~min}$ 陰極面積 $1 \mathrm{dm}^{2}$

陰極電流密度 $3.5 \mathrm{~A} / \mathrm{dm}^{2} \quad$ PR 法 $20 \mathrm{~s}: 5 \mathrm{~s}$

空気カクハン有

銅メッキの操作は口過して懸濁物を除去した後にメッ キしたので, 今回のニッケルメッキ液の実験目的より除 外した。

（ii） 光沢ニッケルメッキ液

(1) 組 成

$\begin{array}{lclll}\text { 硫酸ニッケル } & 250 \mathrm{~g} / l & \text { 塩化ニッケル } & 45 \mathrm{~g} / l \\ \text { ホウ酸 } & 30 " & \mathrm{DNS} & 15 " \\ \text { ブチンジオール } & 0.5 \| & \mathrm{pH} & 4.0 \sim 4.2\end{array}$

(ロ) 操作条件

温度 $45 \sim 50^{\circ} \mathrm{C}$ 液 量 $4 l$

メッキ時間 $20 \mathrm{~min}$ 陰極面積 $1 \mathrm{dm}^{2}$

電流密度 $\quad 4 \mathrm{~A} / \mathrm{dm}^{2}$

(iii）実験用メッキ装置

実験装直は第 3 図に示す。

(1) $4.5 l$ のガラス槽

(ロ) カネカロソ布で陽極袋作成

(少) ストロークポンプで空気カクハン

(二) 電熱による加熱

メッキは, 実験用試片を 5 枚 1 組とし, 同一の濁度に 対して屈曲板 2 回, 平板 3 回行なった。

\section{3. 実験值の評価法および実験結果}

\section{3-1 実験值の評価法}

(i) ピンホールの評価

JIS 規格試験に順じて測定し

$\begin{array}{ccc}\text { ハン点 } 3 \mathrm{~mm} \text { 以上の もの } & 1 \text { 点につき } & 10 \text { 点 } \\ 3 \sim 1 \mathrm{~mm} \text { のもの } & \text { " } & 3 \text { 点 } \\ 1 \mathrm{~mm} \text { のもの } & \text { " } & 1 \text { 点 }\end{array}$

単位面積 $\left(1 \mathrm{~cm}^{2}\right)$ 当たりの数で表わすとともに，5枚 の平均をその濁度の評価とする。

評価フェロキシル試験評価フェロキシル試験 $1 \mathrm{~cm}^{2}$ 当たりハン点数 $\quad 1 \mathrm{~cm}^{2}$ 当たりハン点数

$\begin{array}{lccc}5 & - & 2 & 5 \text { 未.満 } \\ 4 & 1 \text { 未満 } & 1 & 8 \text { " } \\ 3 & 2 \text { " } & & \end{array}$

(ii) ザラッキの評価

薄い方眼紙を試験片にかぶせ，表面を柔いチョークで 摩擦し, 一辺 $5 \mathrm{~mm}$ の正方形 80 個の各々のワク内にザ ラが大小をとわず 1 点以上あれば，そのワク内は発生 1 として評価した。

$\begin{array}{cccccc}\text { 評価 } & \text { 評点 } & \text { 発生個数 } & \text { 評価 } & \text { 評点 } & \text { 発生個数 } \\ 5 & 80 & 0 & 2 & 32 & 49 \\ & 79 & 1 & & \vdots & \vdots \\ & \vdots & \vdots & & 17 & 64 \\ & 65 & 16 & 1 & 16 & 65 \\ 4 & 64 & 20 & & \vdots & \vdots \\ & \vdots & \vdots & & & 80 \\ 3 & 49 & 32 & & & \\ 3 & 48 & 33 & & & \\ & \vdots & \vdots & & & \end{array}$

(iii) 光沢度

観察のみに頼るので主観も入るが，一応次のごとく評 価した。

$\begin{array}{llll}\text { 光沢全面 } & 5 & \text { 光沢 } 3 / 4 & 4 \\ \text { 光沢 1/2 } & 3 & \text { 光沢 } 1 / 4 & 2 \\ \text { 無 光 沢 } & 1 & & \end{array}$

(iv）気ホウ穴の有無

メッキの際発生するガスによるメッキ面のピット

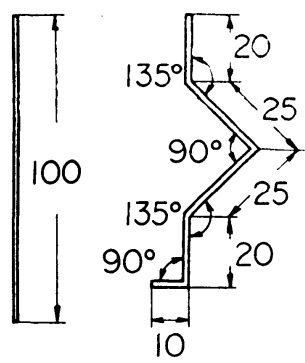

厚廿 $\quad 0.4 \mathrm{~mm}$ 面積 $\quad 0.2 \mathrm{~A} / \mathrm{dm}^{2}$

第2図試験片

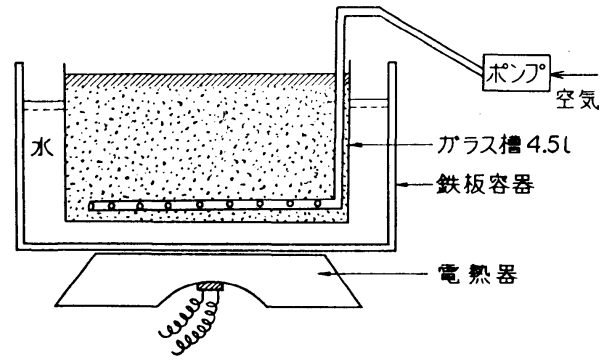

第3図実験メッキ装置
ピット発生なし 5

II $1 / 4$

"1 3

" $3 / 4 \quad 2$

" 全面 1

（v）あらゆる面からみた製品の 外観

商品価値あり

上記より落ちる

やや不良

価値なし

メッキ不良 
第1表 実 娩 結 果

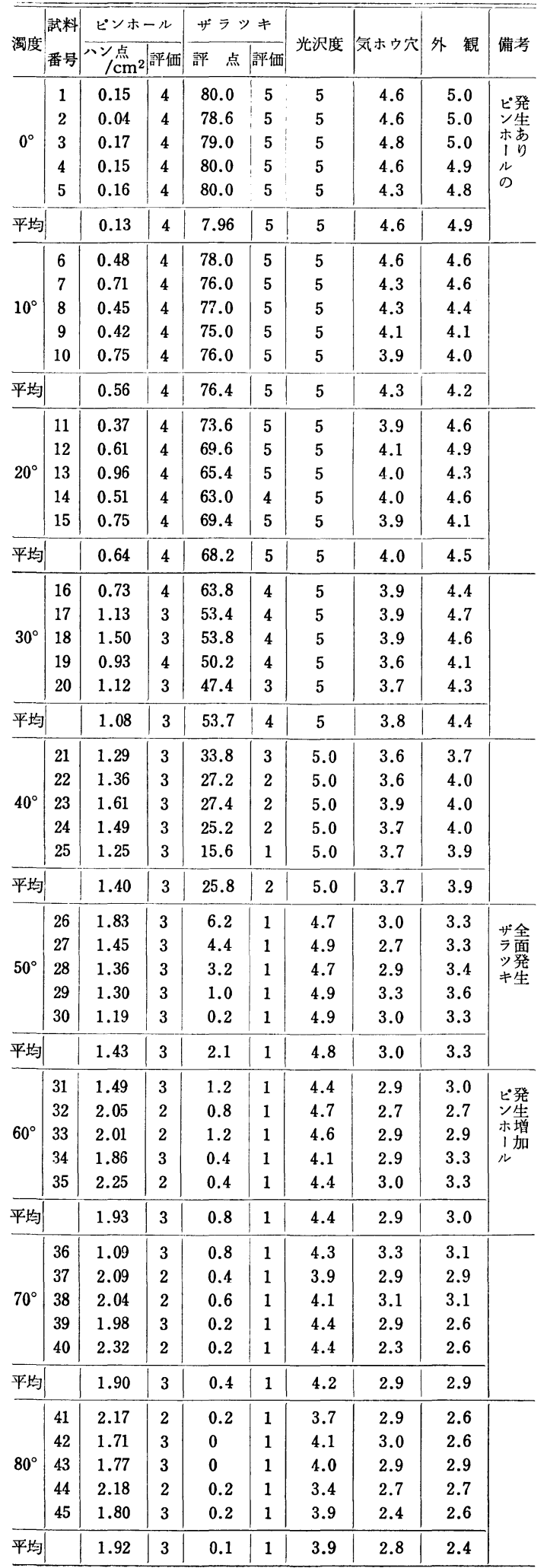

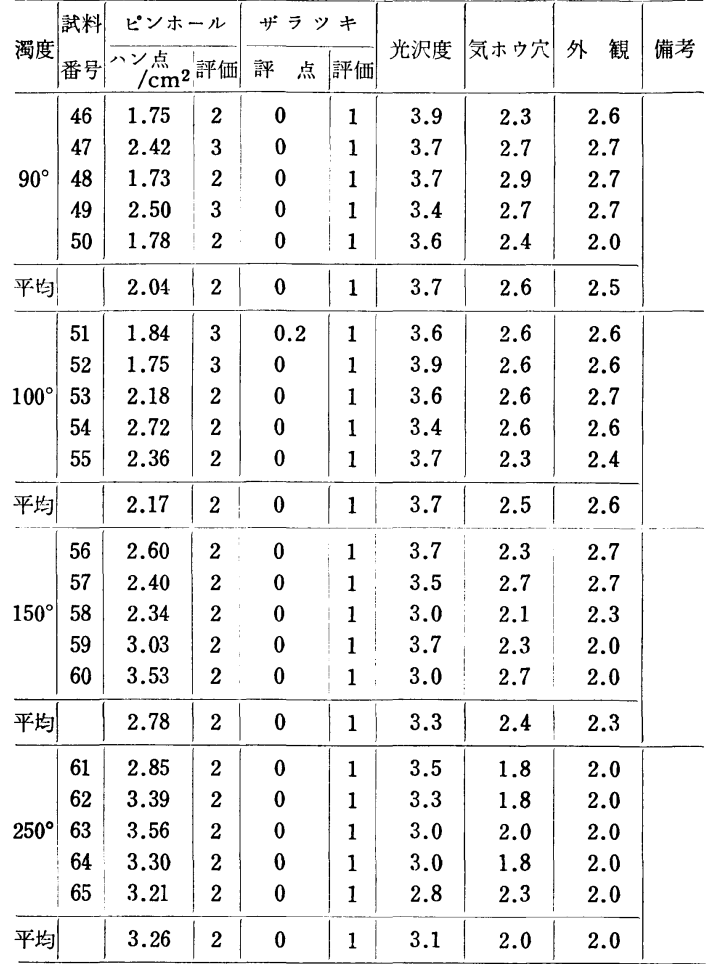

\section{3-2＼cjkstart実験結果および考察}

\section{(i) 実験結果}

第 1 表は, 平板 3 回, 屈曲板 2 回の平均値を示す。

（ii）ピンホール発生と濁度の関係

第 4 図の鎖線で示されている曲線は，平板試験片を同 一濁度について3回メッキした平均結果を, 破線は屈曲 試験片の 2 回についての結果（いずれる実験結果省略） を示したもので，実線が第 1 表の結果である。

これによれば, ピンホールの数はメッキ液中の懸濁物 の量が多くなるにしたがって增加する。

（iii）ザラ発生と濁度の関係

第 1 表のザラと濁度の関係を表わしたのが第 5 図であ る。これによると，ザラッキの発生は濁度が高くなるに したがって爆発的に增加する。

(iv) 綜合評価および考察

第 6 図は第 1 表の実験結果に基づいて，ピンホール， ザラッキ, 光沢度, 気ホウ穴扣よび外観の評価が濁度と どのような関係にあるかを示したものである。

評価項目 および評価值に検討を要する点もあるが, 我々が実験の始めに莫然と考えていた結果，すなわち， ニッケルメッキ液中の微細な懸濁物はメッキ仕上ガリ面 に悪い影響を及ぼすということを，ある程度数量的に確 認することができた。

（イ）ザラッキはわずかな懸濁物によっても極端に発生 


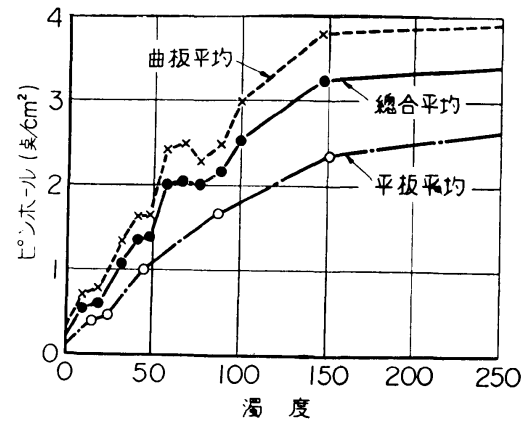

第 4 図ピンホール発生傾向

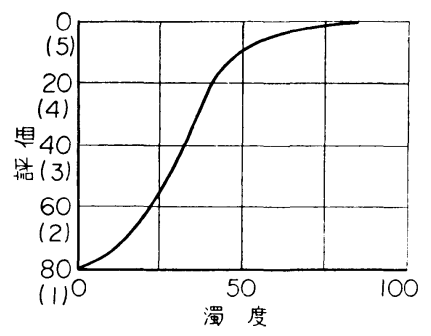

第 5 図ザラツキ発生傾问

し，30度以上になると両者は比例関係を越えて爆発 的な傾向を示す。

（ロ）ピソホール，気ホウ穴打よび外観は100 度付近ま で比例して発生するが, 以後, 濁度の增加にはあま り関係がない。

(ツ) 近年, 光沢剤としてメッキ液中の不純物にある程 度鈍感な薬品が市販されているので, 懸濁物にあま り影響されないが，濁度 50 度以上になると、ザラ ッキなどの発生により光沢を失いはじめる。

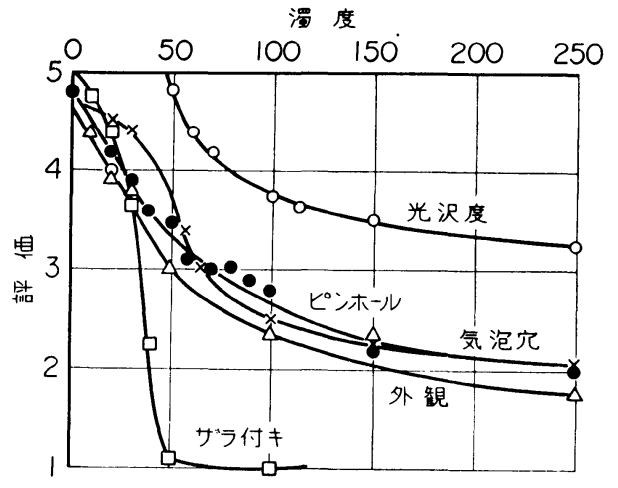

第 6 図総 合評 洒

\section{4. 結 論}

以上，不完全ではあるが，まず光沢メッキ液中の微細 な掱濁物の標準組成を，酸化ニッケル末 $30 \%$ ，酸化第 二鉄末 $50 \%$, 水酸化第二鉄 $20 \%$ とし，これら混合物が メッキ液中に懸濁混入している $\mathrm{ppm}$ 量を濁度として表 示した。

次に, 濁度すなわち懸濁物の量を変化させて, 光沢二 ッケルメッキを行ないメッキ仕上ガリ面を観察した。こ の結果, ピソホール, 気ホウ穴などはある程度濁度と比 例関係にあるが，ザラッキのみはこの比例限界を越えて 急激に增加することが判明した。

このため, 光沢ニッケルメッキ液中の毷濁物の量は $20 \mathrm{ppm}$ 以下に保つことが望ましいという結論に達した。 終りに本研究に対してご指導を賜わった名古屋工業技 術試験場の林禎一博士にあつく扮礼申し上げる。

(1962. 12.3 受理)

\section{金属表面技術天然色オートスライド完成 （頒布中）}

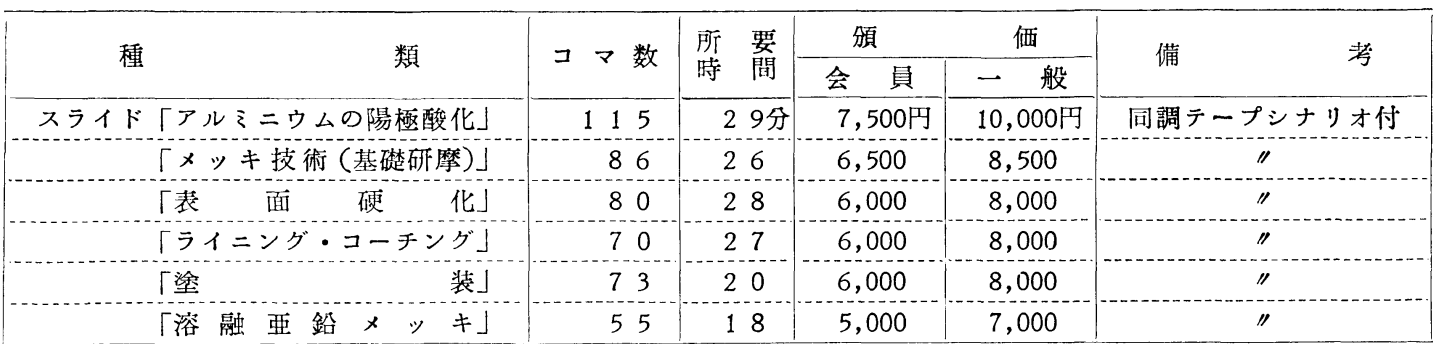

1. 頒布希望品目, 数量, 社名, 所在地, 担当者（所属部課名とも）を明記の上, 代金招よび発送料を添えて申 し込んで下さい。

2. 申达日から約 10 日目に品物を报湾しします。

3. 頒価には発送料（包装料，発送郵税）などは含まれていないので実費（1本の場合 300 円，2〜3本 400 円， 4 本以上 500 円）を申し受けます。

4. 受領済の代金は一切返却しません。

5.頒布をうけたスライドの模写複製等を禁じます。

6. 申达先 東京都千代田区神田岩本町 2 共同ビル 金属表面技術協会 スライド係 